DOI: $10.2478 / \mathrm{v} 10025-008-0009-y$

JOURNAL OF WATER

AND LAND DEVELOPMENT

J. Water Land Dev. No. 11, 2007: 103-116

\title{
Factors affecting water quality in degraded sewage receivers - case study of the phosphorus dynamics in the Ner River
}

\author{
Józef MOSIEJ, Hubert KOMOROWSKI, Agnieszka KARCZMARCZYK
}

Warsaw University of Life Sciences (WULS-SGGW) Department of Environmental Improvement

\begin{abstract}
No adequate reaction has been observed of the decreased contaminant loads discharged by Łódź, particularly the loads of phosphorus, on its concentration in the Ner River. That's why the impact of sediment on phosphorus content in the water was evaluated. Not only was the amount of phosphorus taken under consideration but also the equilibrium phosphate concentration (EPCo). The meaning of EPCo is that any phosphate concentration in the water below this value will lead to phosphorus release from sediments. Performed study shows that in the Puczniew cross-section EPCo is higher then phosphorus concentration in water, thus with mean concentration of $\mathrm{PO}_{4}$ equal to $9.5 \mathrm{mg}$ $\mathrm{PO}_{4} \cdot \mathrm{dm}^{-3}$ phosphorus could be released from sediments. This concentration in Lutomiersk cross-

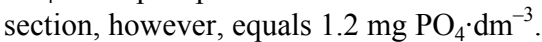

Key words: equilibrium phosphate concentration (EPCo), phosphorus release, reclamation, sediments, sewage receiver

\section{INTRODUCTION}

The Ner River and its valley for over 100 years received sewages from the city of Łódź. The natural system of this region (location at the border of the watershed, limitations of water supply resources and a lack of large natural rivers) and the development of the municipality formed a specific system composed of the city agglomeration, water supplies and sewage treatment system. An amount of sewage discharged to the Ner is several times larger then its natural water flow being a result of the water supply strategy based on water transfer from the Pilica River and on underground water uptake. Relatively high runoff coefficient for the Ner in the years 1952-1980 was equal to 0.325 as compared with 0.17 for other rivers in the Warta watershed. It is an evidence of anthropogenic changes of the river caused by discharging the sewage in amount of $450000 \mathrm{~m}^{3}$ per day (in 1992), which makes a $90 \mathrm{~mm}$ increase of the runoff coefficient (PASŁAWSKI, 1992). 
Closing many factories in the Łódź region and constructing wastewater treatment plant (WWTP) of the Łódź City Agglomeration (ŁCA) significantly improved water quality in the river; it still, however, does not meet the assumed level. Still during the construction of the wastewater treatment plant it was remarked that after its start, river water quality would not be significantly improved since the outflow from treatment facility was over 10 times larger then the natural water flow. This fact could also pose some problems in river reclamation (URBANIAK, 1997; URBANIAK and PRZYBIŃSKI, 1997).

Irrigation with the water from the Ner significantly affected water quality improvement and environmental status of the valley. Irrigation water covered the shortages in soil humidity but was also used as fertilizer. It was assessed that the irrigated area of c. 4300 ha (in the years 1980-1995) received $13 \%$ and $34 \%$ of sewages from the Łódź Agglomeration in the wet and dry year, respectively (MOSIEJ, 1999). The discharge of raw sewage to the Ner caused the accumulation of sediments in the river bed and in the valley. Irrigation of mineral sandy soils in the valley resulted in the formation of anthropogenic soils with high content of organic substances (up to $5 \%$ in the 0-20 cm layer) and brought the risk of heavy metals accumulation (MosieJ, 1999; MulTan, 1993, 1996; Multan and SZATYŁOWICZ, 1993; SOMOROWSKI et al., 1991). On the other hand, the use of contaminated river water for irrigation improved water quality due to plant uptake and soil filtration.

The level of contamination of the Ner River and its impact on the quality of the Warta River needs radical actions because of the role this water resource plays in the whole region. Despite the construction of the WWTP there are still some actions needed which could help improving the quality of water in the Ner and Warta by rational use of the existing and implementing new solutions (ILNICKI et al., 2003).

The aim of this work was to analyze the reasons of low water quality in the Ner River with special focus on the impact of sediment and settled phosphorus on water contamination. The main goal of the study was, however, to evaluate the possibility of reclamation of the river degraded by long sewage disposal. The main symptom of degradation is the amount of accumulated sediment which might lead to internal contamination.

\section{STUDY SITE AND METHODS}

The Ner is a small lowland river, right side tributary of the Warta. The river has its springs at $208 \mathrm{~m}$ a.s.l. situated near Wiśniowa Góra south east of Łódź, while its outlet is situated at $444.4 \mathrm{~km}$ of the Warta course. River length is $125.9 \mathrm{~km}$. The Ner catchment basin (Fig. 1) comprising 3.5\% of the Warta drainage basin covers an area of $1866 \mathrm{~km}^{2}$ and is situated in central Poland (BEDNARCZYK, 1997). Three 


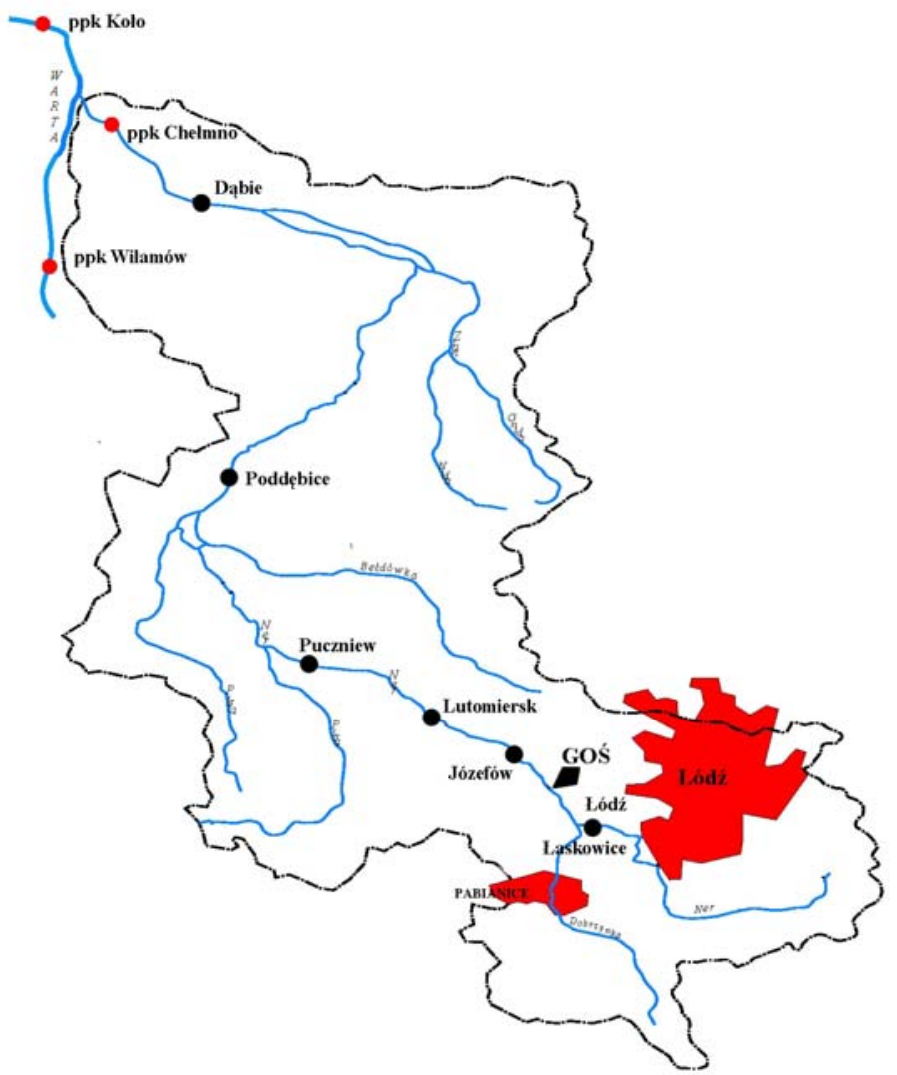

Fig. 1. The Ner catchment basin with the water quality control points

large cities situated at the southern borders of the Ner catchment basin: Łódź, Pabianice and Konstantynów Lódzki with a total population of approximately 0.9 million people form together the Łódź City Agglomeration. Ninety percent of sewages from that agglomeration is treated by wastewater treatment plant. For many years partly treated sewages (only pre-treated till 1997) discharged to the river caused huge contamination of its waters.

The Ner watershed is typically agricultural. Nowadays agricultural lands cover $69 \%$ of the total area including $55.9 \%$ arable lands and $13 \%$ grasslands. The catchment is covered with forests in $12.2 \%$ while urbanization is intense especially in its upper part.

The main sources of pollution in the watershed are point sources from the city, industry and country side. Sewages from ŁCA after being treated in WWTP are discharged to the Ner by sewage collector. In the years 1994-1999 the amount of sewage from Łódź decreased from 318000 to $225000 \mathrm{~m}^{3}$ per day. In 1996 the first technological line with biological sewage treatment of a capacity of $150000 \mathrm{~m}^{3}$ per 
day started to operate. Since 1998 about $50 \%$ and since 2001 over $90 \%$ of sewages from ŁCA were biologically treated. In 2003 the WWTP treated $203500 \mathrm{~m}^{3}$ per day on average and about $188000 \mathrm{~m}^{3}$ per day during dry weather. Mean annual concentrations of selected contaminants at the outflow from WWTP were: $\mathrm{BOD}_{5}$ $10.1 \mathrm{mg} \mathrm{O} \cdot \mathrm{dm}^{-3}$; phosphorus $1.1 \mathrm{mg} \cdot \mathrm{dm}^{3}$, nitrogen $23.8 \mathrm{mg} \cdot \mathrm{dm}^{-3}$ and suspended solids $22.5 \mathrm{mg} \cdot \mathrm{dm}^{-3}$ with the respective reduction equal to $96,85,53$ and $88 \%$. Nowadays sewages from WWTP are treated mechanically, biologically and chemically.

The assessment of changes in phosphorus concentration and load in the Ner River from WWTP to Chełmno cross section for the years 1999-2003 was based on comparison of the load and concentration of phosphorus compounds in sewages from treatment facilities and the Ner River closing cross section.

The load of phosphorus was calculated from measurements made within the state environmental monitoring system in the Ner and Warta Rivers and from the water flow in control points in the Warta River (Wilamów and Koło cross sections) and the Ner River (Chełmno cross section) (Fig. 1). Mean annual load of contaminants was calculated as a product of mean annual flow in a given cross section and mean annual concentration of a given parameter taken from official publications by Voivodship Inspectorate of Environmental Protection (WIOŚ) in Konin and Poznań. Mean annual flows for the years 1995-2003 were calculated by IMGW (Institute of Meteorology and Water Management) in Poznan for the Chełmno cross section (the Ner River) based on water gauge records in Dąbie; for Wilamów (the Warta River) based on water gauge records in Uniejów; for Koło (the Warta) based on water gauge records in Dąbie and Uniejów.

Three periods respective to subsequent installations in WWTP can be distinguished within the study period from 1995 to 2003. Only mechanical part was operating in the years 1995-1997, biological part started to operate in the years 19982000 (50\% discharged sewages) and achieved its full efficiency in the years 20012003.

Sediments were analysed in November 2003. Top layer $(5 \mathrm{~cm})$ of sediment was taken in the cross sections in: Łódź - Laskowice, Józefów, Lutomiersk, Puczniew, and Poddębice. The content of phosphorus fractions in sediment was analysed with the method of PSENNER and PUCSKO (1998). Samples (5 g) of sediments were subsequently extracted with: $1 \mathrm{M} \mathrm{NH}_{4} \mathrm{Cl}$ (loosely bound $\mathrm{P}$ ), the 1:1 mixture of $0.11 \mathrm{M} \mathrm{NaHCO}$ and $0.11 \mathrm{M} \mathrm{Na}_{2} \mathrm{~S}_{2} \mathrm{O}_{4}$ (iron bound $\mathrm{P}$ ), $1 \mathrm{M} \mathrm{NaOH}$ (aluminum and organic matter bound $\mathrm{P}$ ) and $0.5 \mathrm{M} \mathrm{HCl}$ (calcium bound $\mathrm{P}$ ).

Equilibrium phosphate concentration (EPCo) of the sediment was determined according to HAUSE'S and DENISON'S method (1999). Samples (5 g) of sediments were shaken for 24 hours in solutions of phosphate of a concentration varying from 0 to $30 \mathrm{mg} \mathrm{PO}_{4} \cdot \mathrm{dm}^{-3}$. EPCo was calculated based on linear equation of the Langmuir's isotherm (MCKAY, 1996). 


\section{RESULTS}

\section{CHANGES OF SOME CONTAMINANTS ALONG THE NER RIVER IN 2004}

Changes of concentrations of some pollutants along the Ner River are shown in graphs (Fig. 2). The point between Łódź and Józefów where the sewages are discharged from WWTP to the river is also marked there. An increase of pollutant concentrations in Józefów cross section caused by the discharge of treated sewages from WWTP may be seen in graphs. Further increase of analysed chemical species took place down to the Lutomiersk cross section. In the Lutomiersk cross section nitrogen concentration of $35 \mathrm{mg} \cdot \mathrm{dm}^{-3}$ highly exceeded the limit for the $4^{\text {th }}$ class water quality $\left(20 \mathrm{mg} \cdot \mathrm{dm}^{-3}\right)$. $\mathrm{BOD}_{5}$ concentration in this cross section in the year 2004 was $170 \mathrm{mg} \cdot \mathrm{dm}^{-3}$ i.e. 12 -fold the limit for the $4^{\text {th }}$ class water quality. Phosphorus concentration exceeded the respective limit almost seven times. In view of these results the main goal of planned reclamation should be to increase water quality to the $3^{\text {rd }}$ class. It can be difficult to achieve due to possible internal input of phosphorus from sediments to water.

THE INFLUENCE OF PHOSPHORUS LOAD FROM ŁÓDŹ ON ITS CONCENTRATIONS IN THE WARTA AND NER RIVERS

Mean annual water flows in analysed profiles of the Ner and Warta Rivers are given in Table 1. Mean water flow in the Ner in the analysed period was $11.6 \mathrm{~m}^{3} \cdot \mathrm{s}^{-1}$ which constituted c. $10 \%$ of water flow in the Warta downstream the Ner outlet (the Koło cross section). The share of phosphorus load was higher and equalled $37 \%$. In the years 1995-2000 before biological sewage treatment in WWTP this share was higher then the mean being equal to $41 \%$. Since 2001 the share of phosphorus load decreased below the mean and was equal to $29 \%$.

Concentrations of phosphorus in the Chełmno cross section during the study period were $1.2 \mathrm{mg} \cdot \mathrm{dm}^{-3}$ on average. Till 2000 concentrations of phosphorus qualified the waters to the $5^{\text {th }}$ class. After biological treatment started in WWTP the concentrations of phosphorus decreased and water quality increased to the $3^{\text {rd }}$ class. Downstream the Ner outlet to the Warta the phosphorus concentration was observed to increase (by c. 50\%), it didn't, however, decline the water quality classification rate.

Loads of phosphorus discharged from WWTP decreased during the study period (Tab. 2). Until the year 2000 phosphorus load in waste waters discharged to the river was higher then its load in closing profile in Chełmno probably as an effect of self-purification processes. However, since 2001, after further reduction, the load of phosphorus in closing cross section in Chelmno was higher then the load in sewages. 

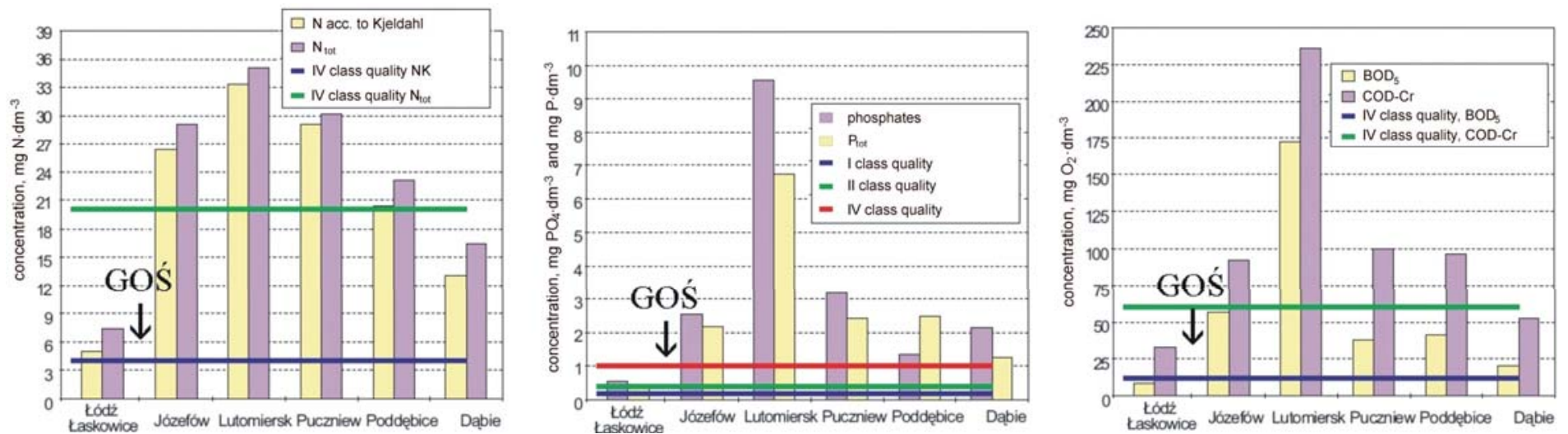

Fig. 2. Changes in the concentrations of nitrogen, phosphorus and oxygen demand in the Ner River in 2004 (based on WIOŚ 2005) 
Table 1. Mean annual flows, concentrations and loads of phosphorus in the Ner River (Chełmno cross section), the Warta River upstream the Ner outlet (Wilamów cross section) and in the Warta River downstream the Ner outlet (Koło cross section) for the years 1995-2003

\begin{tabular}{|c|c|c|c|c|c|c|c|c|c|}
\hline \multirow[b]{2}{*}{ Years } & \multicolumn{3}{|c|}{$\begin{array}{c}\text { The Ner River } \\
\text { Chełmno }\end{array}$} & \multicolumn{3}{|c|}{$\begin{array}{c}\text { The Warta River } \\
\text { Wilamów }\end{array}$} & \multicolumn{3}{|c|}{$\begin{array}{c}\text { The Warta River } \\
\text { Koło }\end{array}$} \\
\hline & $\begin{array}{l}\text { flow } \\
\mathrm{m}^{3} \cdot \mathrm{s}^{-1}\end{array}$ & $\begin{array}{l}\text { concen- } \\
\text { tration } \\
\underset{3}{\mathrm{mg} \cdot \mathrm{dm}^{-}}\end{array}$ & $\begin{array}{c}\text { load } \\
\mathrm{Mg} \cdot \mathrm{y}^{-1}\end{array}$ & $\begin{array}{l}\text { flow } \\
\mathrm{m}^{3} \cdot \mathrm{s}^{-1}\end{array}$ & $\begin{array}{l}\text { concen- } \\
\text { tration } \\
\underset{3}{\mathrm{mg} \cdot \mathrm{dm}^{-}}\end{array}$ & 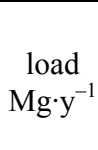 & $\begin{array}{l}\text { flow } \\
\mathrm{m}^{3} \cdot \mathrm{s}^{-1}\end{array}$ & $\begin{array}{l}\text { concen- } \\
\text { tration } \\
\underset{3}{\mathrm{mg} \cdot \mathrm{dm}^{-}}\end{array}$ & $\begin{array}{c}\text { load } \\
\mathrm{Mg} \cdot \mathrm{y}^{-1}\end{array}$ \\
\hline 1995 & 9.92 & 2 & 625 & 43.3 & 0.17 & 232 & 81 & 0.58 & 1481 \\
\hline 1996 & 8.89 & 2.3 & 644 & 43.4 & 0.25 & 342 & 79.6 & 0.57 & 1430 \\
\hline 1997 & 9.83 & 1.3 & 402 & 57.7 & 0.18 & 327 & 103 & 0.49 & 1591 \\
\hline 1998 & 12.1 & 1.61 & 614 & 63.2 & 0.36 & 717 & 115 & 0.51 & 1849 \\
\hline 1999 & 18.5 & 1.14 & 665 & 62.8 & 0.11 & 217 & 123 & 0.29 & 1124 \\
\hline 2000 & 10.1 & 1.1 & 350 & 53.1 & 0.12 & 200 & 96.2 & 0.29 & 879 \\
\hline 2001 & 14.7 & 0.63 & 292 & 72.8 & 0.1 & 229 & 133 & 0.26 & 1090 \\
\hline 2002 & 13 & 0.52 & 213 & 61.2 & 0.13 & 250 & 113 & 0.19 & 677 \\
\hline 2003 & 7.59 & 0.6 & 143 & 39.6 & 0.11 & 137 & 70.9 & 0.21 & 469 \\
\hline Mean & 11.6 & 1.2 & 439 & 55.2 & 0.17 & 295 & 101.6 & 0.38 & 1177 \\
\hline
\end{tabular}

Table 2. Comparison of the amount of phosphorus in sewages discharged into the Ner River from Łódź, Poddębice and Pabianice with the load of contaminants in the Chełmno cross section (data from WIOŚ)

\begin{tabular}{|c|c|c|c|c|c|c|}
\hline \multirow[b]{2}{*}{ Year } & \multirow{2}{*}{\begin{tabular}{|c|}
$\begin{array}{c}\text { Amount } \\
\text { of sewage } \\
\mathrm{m}^{3} \cdot \mathrm{s}^{-1} \\
\end{array}$ \\
\end{tabular}} & \multirow{2}{*}{$\begin{array}{c}\text { Flow of the Ner River } \\
\text { in Chełmno } \\
\mathrm{m}^{3} \cdot \mathrm{s}^{-1}\end{array}$} & \multicolumn{2}{|c|}{ Load of $\mathrm{P}_{\text {tot. }}, \mathrm{Mg} \cdot \mathrm{y}^{-1}$} & \multicolumn{2}{|c|}{$P_{\text {tot. }}, g \cdot \mathrm{m}^{-3}$} \\
\hline & & & sewage & Ner Chełmno & sewage & Ner Chełmno \\
\hline 1999 & 2.8 & 18.5 & 336 & 665 & 3.8 & 1.1 \\
\hline 2000 & 2.9 & 10.1 & 584 & 350 & 6.4 & 1.1 \\
\hline 2001 & 2.7 & 14.7 & 271 & 292 & 3.2 & 0.6 \\
\hline 2002 & 2.7 & 13 & 97 & 213 & 1.1 & 0.5 \\
\hline 2003 & 2.4 & 7.6 & 83 & 143 & 1.1 & 0.6 \\
\hline 2004 & 2.3 & no data & 78 & no data & 1.1 & 1.1 \\
\hline
\end{tabular}

Lower concentrations of phosphorus (below $4 \mathrm{~g} \cdot \mathrm{m}^{-3}$ ) in sewages discharged from treatment facility to the Ner River were not followed by the adequate improvement of water quality observed in the Chełmno profile (Tab. 2). Despite further reduction of phosphorus in sewages in the years 2002-2004 the $\mathrm{PO}_{4}$ concentrations in the Chełmno profile did not decrease below $0.5 \mathrm{mg} \mathrm{PO}_{4} \cdot \mathrm{dm}^{-3}$ and in the year 2004 it even increased up to $1.1 \mathrm{mg} \mathrm{PO}_{4} \cdot \mathrm{dm}^{-3}$.

Analyses of changes in phosphorus concentrations at selected control points in the Ner River revealed that significant decrease of phosphorus loads discharged 
from WWTP did not result in respective changes of $\mathrm{P}$ concentrations in profiles downstream (Fig. 3). Mean annual values of phosphorus concentration and $\mathrm{BOD}_{5}$ in Józefów, Lutomiersk and Puczniew situated upstream the outlets of the main tributaries: the Pisa and the Pisia did not decrease significantly along the river course and in some years their concentrations were observed to increase. Reduction of $\mathrm{P}$ and $\mathrm{BOD}_{5}$ was observed till 2000 when the load of phosphorus discharged from the WWTP was remarkable. After the year 2000 the increase of studied concentrations was observed along this $25 \mathrm{~km}$ long river section. It is an evidence of decreasing river potential to self purification and probable intensification of phosphorus release from sediments caused by the decrease of phosphate concentration in the river below the equilibrium concentration EPCo.

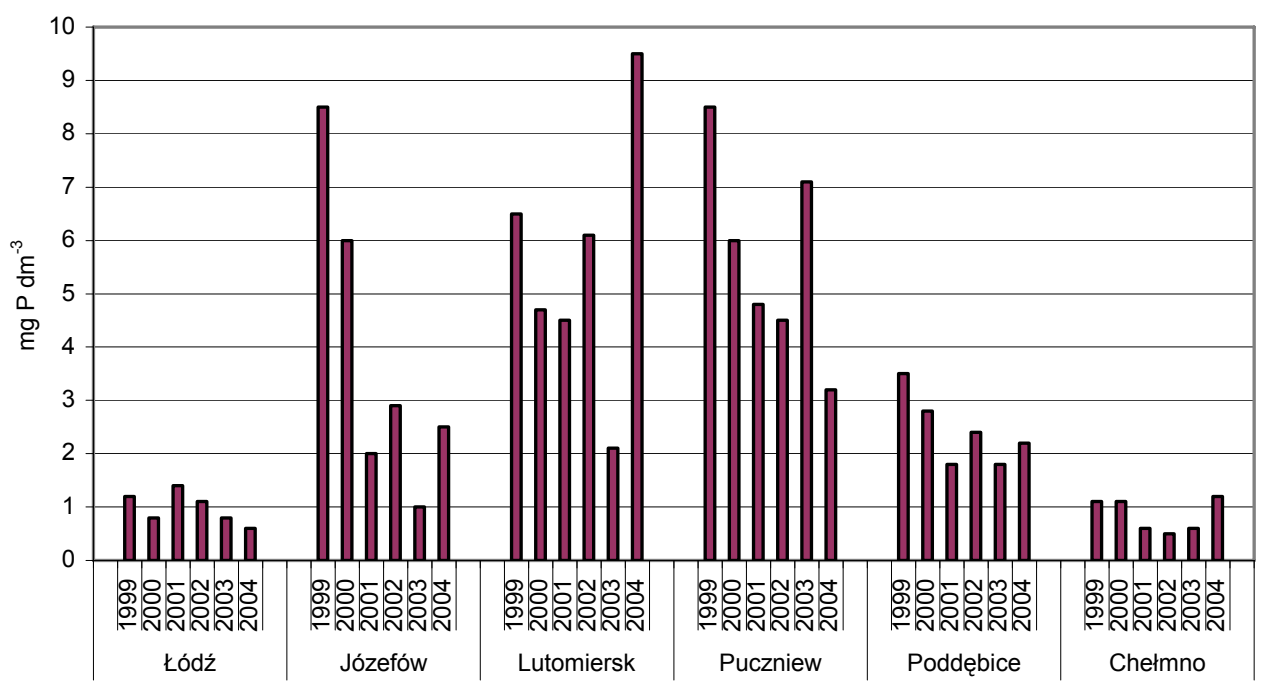

Fig. 3. Changes in phosphorus concentration in the years 1999-2004 in selected control points

\section{INFLUENCE OF THE SEDIMENTS ON PHOSPHORUS CONTENT IN THE NER RIVER}

A lack of adequate response to decreasing phosphorus load discharged by WWTP may be an effect of releasing phosphorus from sediments which buffers the concentration of phosphorus in water. Depending on phosphorus concentration in the water, sediments may adsorb or release phosphorus to achieve equilibrium between water and sediments (SHEFFER, 1998). That is the reason why in many cases not only the content of phosphorus in sediment is taken under consideration but also the EPCo value. According to definition EPCo is such a concentration of phosphates in water overlying sediments that ensures equilibrium between sorption and desorption (HAUSE and DENISON, 2000). In the case of contact with water 
whose phosphorus concentration is lower then the EPCo the sediments release phosphorus and water is again enriched in this element. Studies of sediments and the EPCo in the Ner demonstrated that this process could be the reason for increasing phosphorus concentrations in the water (Fig. 4 and 5). In the Lutomiersk cross section the EPCo was over $1.2 \mathrm{mg} \mathrm{PO} \cdot \mathrm{dm}^{-3}$ and thus higher than standards for the $4^{\text {th }}$ class water quality. It means that every concentration of phosphates in the river below this value will cause desorption of phosphorus from the sediment. These sediments settled in the conditions of intensive human impact (long term outflow of raw sewage over 10 times higher then the natural water flow) at high concentrations of contaminants, low content of oxygen and different conditions of deposition (high flows, regulation of river basin, hydro technical facilities etc.). Therefore, the values of EPCo for these sediments are so spatially different and in some control points so high.

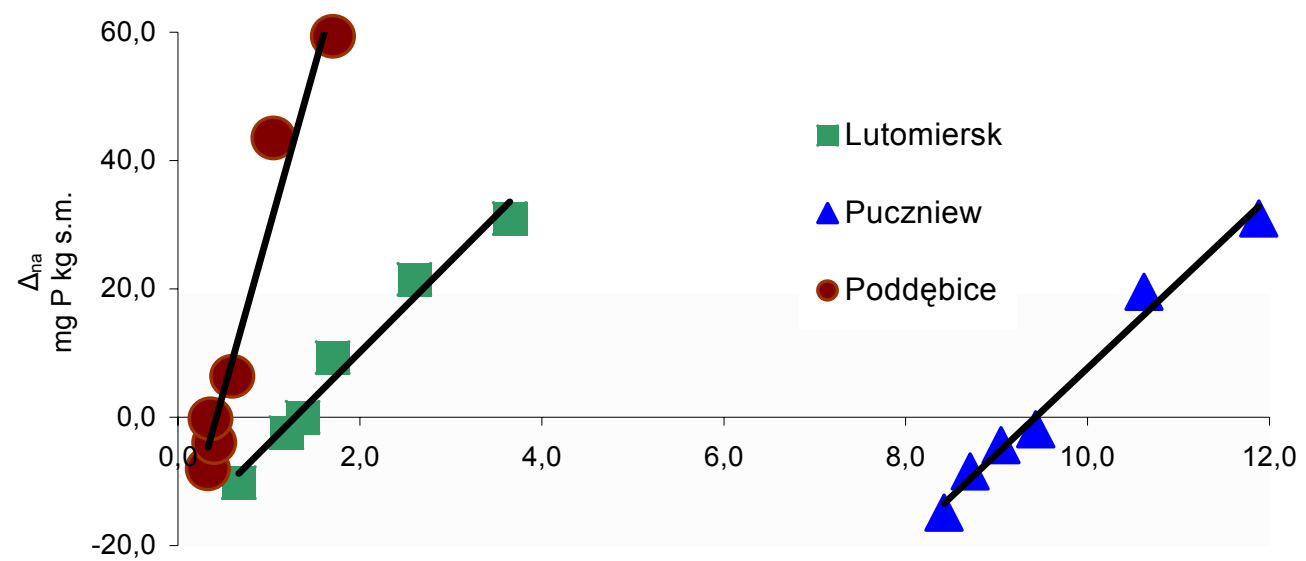

Concentration of phosphorus in the solution after $24 \mathrm{~h}$ $\mathrm{mg} \mathrm{PO}_{4} \mathrm{dm}^{-3}$

Fig. 4. Experimental data of laboratory investigation on the EPCo in selected sediment samples shown as adsorption isotherms after 24 hours; $\Delta_{\mathrm{na}}$ - changes in adsorbed phosphorus in the sediment during the experiment - values $\Delta_{\mathrm{na}}<0$ mean phosphorus desorption from the sediment

The main problem for $25 \mathrm{~km}$ long section of the Ner River (from the input of treated waste waters to Puczniew) is to establish how long and intensive will be the impact of sediments on running water. This question needs further studies. In lakes this phenomenon is quite well known and considered to be one of the factors accelerating eutrophication. In flowing waters the problem has not been acknowledged so far mainly because of the greater importance of other sources of pollution. 


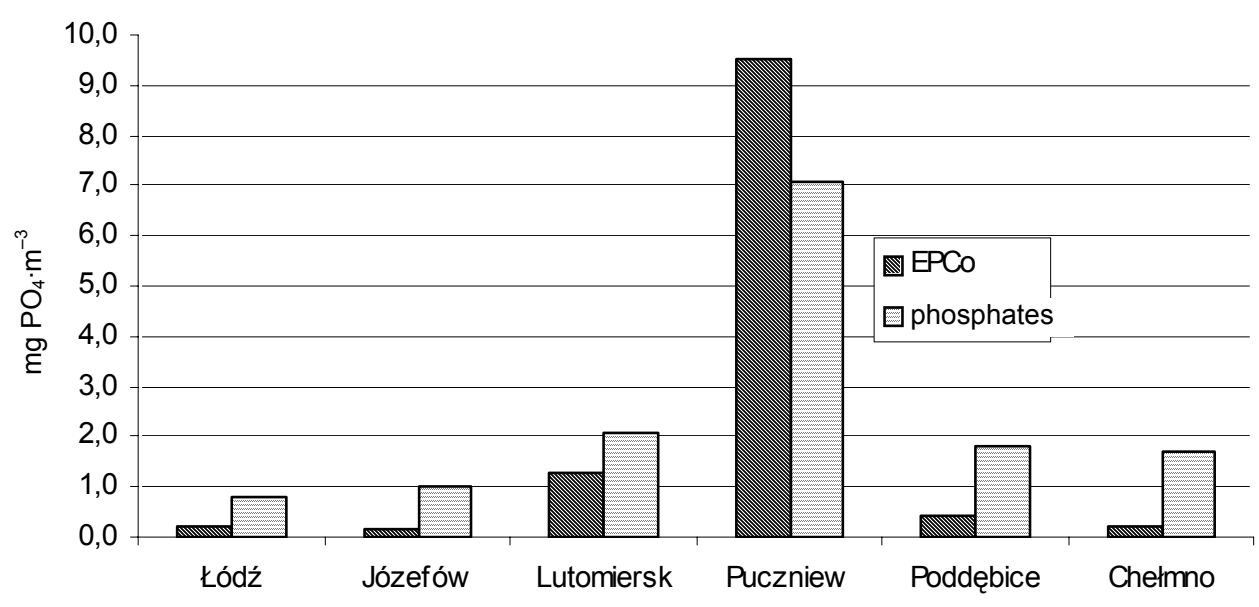

Fig. 5. Comparison of the sediment EPCo and concentrations of phosphates in water from selected profiles in the Ner River

Phosphorus sorption and desorption in sediment proceeds continuously. Under natural conditions total balance of the two processes is close to zero and does not affect water quality. On the other hand the sediment is a kind of phosphorus reserve and may affect its concentration in the water. Phosphorus may occur in sediments in different physical and chemical bounds. Five main fractions of phosphorus are distinguished depending on its mobility: loosely bound fraction $-\mathrm{NH}_{4} \mathrm{Cl}-\mathrm{P}$, iron bound phosphorus - Fe-P, aluminium and organic matter bound phosphorus $\mathrm{NaOH}-\mathrm{P}$, calcium bound phosphorus - HCl-P and residual $\mathrm{P}$ fraction (PSENNER and PUCSKO, 1998). The mechanism of phosphorus release from sediments is very complex. Sorption, desorption and microbial decomposition play important roles but redox conditions, water flow, temperature and $\mathrm{pH}$ are also the significant factors (KIM et al., 2002; STUMM and MORGAN, 1996).

The intensification of phosphorus release from sediments to water may occur at rapid changes of its concentration in water. Such phenomenon was observed in Lake Sobygaard where the rapid, distinct decrease of loads delivered to the lake was followed by negative retention of phosphorus in the sediments which meant that large amounts of phosphorus were released from sediment to the water body (SONDERGAARD et al., 1993). Similar example of swamps which in the past were under strong human impact shows that not only phosphorus but other contaminants were released from sediments and became their main source of input to water (LAU and CHU, 1998). According to JEPPESEN et al. (1991) disrupting the phosphorus equilibrium between water and sediment after decreasing external, anthropogenic loads may last in lakes for several years. It significantly delays achieving noticeable improvement of water quality after reduction of waste water load to the water body. 
Analyses of sediments in the Ner River showed the highest content of phosphorus $\left(4 \mathrm{mg} \cdot \mathrm{g}^{-1}\right.$ dry matter) in sediment in the Lutomiersk and Puczniew cross sections. Over $95 \%$ of this content constituted easily available fractions of $\mathrm{NH}_{4} \mathrm{Cl}-\mathrm{P}, \mathrm{Fe}-\mathrm{P}$ and NaOH-P (Fig. 6). It shows that $25 \mathrm{~km}$ long river section from the treatment facility to Puczniew has large reserves of this element in sediments which could be released for many years and thus significantly delay achieving the expected water quality.

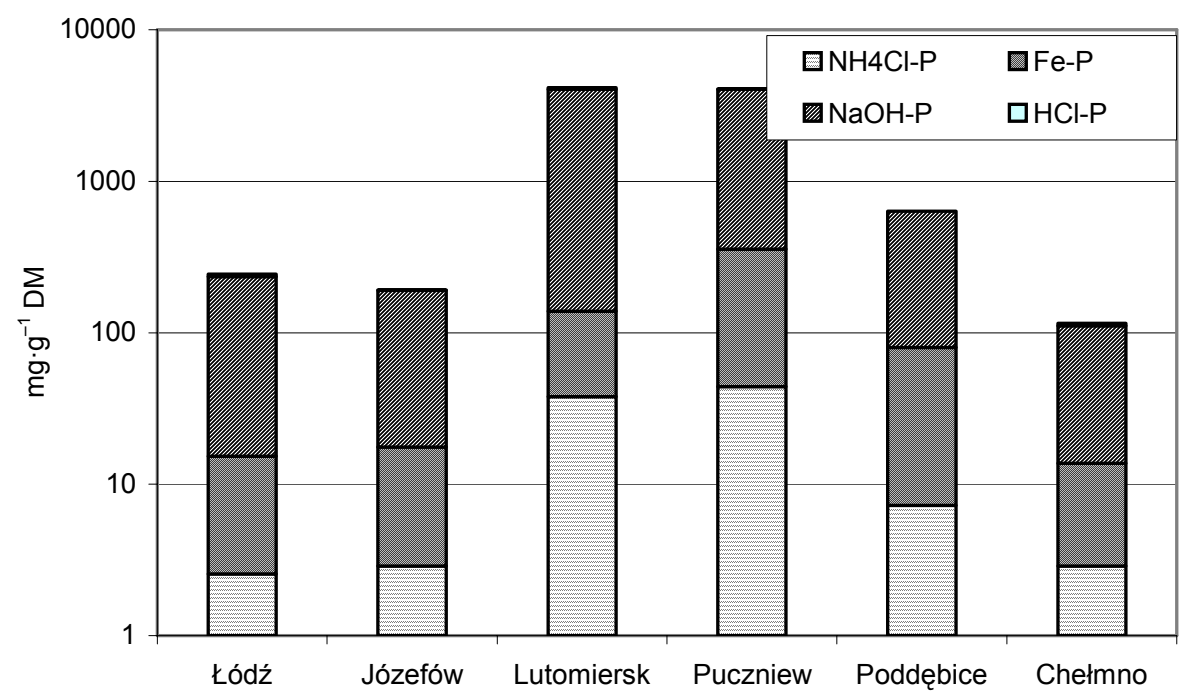

Fig. 6. The content of phosphorus fractions in selected profiles of the Ner River. Division into the fractions according to PSENNER and PUCSKO (1988): loosely bound $\mathrm{P}-\mathrm{NH}_{4} \mathrm{Cl}-\mathrm{P}$, phosphorus fraction connected with iron Fe-P, phosphorus fraction connected with aluminum and organic matter $\mathrm{NaOH}-\mathrm{P}$, phosphorus fraction connected with calcium HCl-P

\section{SUMMARY}

The Ner River despite its low flow delivers relatively large load of contaminants to the Warta River every year. Mean annual flow of the Ner in the study period was equal to c. $10 \%$ of the Warta River downstream (the Koło cross section) flow. The mean share of phosphorus loads was 37\%. In the years 1995-2000 before biological and chemical waste water treatment the share of phosphorus load was $41 \%$ and after 2000 it decreased to $29 \%$.

Concentrations of phosphorus along $25 \mathrm{~km}$ long section of the Ner River from the WWTP to Puczniew had decreased only before biological part of the treatment facility started to operate. After significant decrease of phosphorus concentrations (below $4 \mathrm{mg} \mathrm{P} \cdot \mathrm{dm}^{-3}$ ) at the outlet from the treatment facility in the year 2001 in- 
river phosphorus concentrations from the Józefów to Puczniew cross sections were rising. It indicates the decrease of self-purification potential of the river and probable intensification of phosphorus desorption from sediment. Concentration of phosphates in the river in the years 2001-2004 originated mainly from autochthonous processes whose influence was larger then that from the WWTP. It means that water was re-contaminated from river sediments. Therefore, even highly effective sewage treatment in the WWTP is not able to significantly improve water quality in the Ner River. Achieving a good water quality will be possible only in the case of integrated actions undertaken in the river and its valley by including the valley into the system of sewage treatment in Łódź. According to some studies the use of contaminated water from the Ner for irrigation would significantly improve its quality and this way agriculture would exert positive effect on the loads of pollutants in studied watershed.

Studies referred not only to phosphorus content in the sediment but also to the EPCo. It was very important factor since any in-river concentration of phosphates below this value would lead to their release from sediments. Analyses in the Puczniew profile revealed that the EPCo there $\left(9.5 \mathrm{mg} \mathrm{PO}_{4} \cdot \mathrm{dm}^{-3}\right)$ was higher than the concentration of phosphorus in water which means phosphorus release at the concentration in water below this value. However, the EPCo in the Lutomiersk profile was $1.2 \mathrm{mg} \mathrm{PO}_{4} \cdot \mathrm{dm}^{-3}$. The reason for this was high phosphorus content in sediments with large percent (95\%) of its easily soluble fractions.

\section{REFERENCES}

1. BednARCZyK J., 1997. Wpływ miejskich i przemysłowych ścieków zrzucanych przez aglomerację łódzką na degradację środowiska naturalnego i wody w zlewni rzeki Ner oraz w rzece Warcie. (Influence of municipal and industrial waste water discharged by Łódź Aglomeration on environmental degradation and surface water in the Ner river catchment and the Warta river). W: Woda jako czynnik warunkujący wielofunkcyjny i zrównoważony rozwój wsi i rolnictwa. Mater. Konf. Falenty, Wydaw. IMUZ: 139-146.

2. HAUSE W.A., DENISON F. H., 2000. Factors influencing the measurement of equilibrium phosphate concentration in river sediments. Water Res., 34, 4: 1187-1200.

3. ILNICKI P., BANASZKIEWICZ H., BUKOWSKI Ł., 2003. Źródła, stężenie i ładunki azotu i fosforu w wodach rzeki Ner w latach hydrologicznych 1992-1997. (Sources, concentrations and loads of nitrogen and phosphorus in the Ner River in the period 1992-1997). Acta Sci. Pol. Ser. Formatio Circumiectus 2(1): 23-34.

4. Jeppesen E., Kristensen P., Jenson J.P., Søndergaard M., Mortensen E., Lauridsen T.L., 1991. Recovery resilience following reduction in external phosphorus loading of shallow eutrophic Danish lakes: duration, regulation factors and methods for overcoming resilience. Memorie dell'Instituto Italiano di Idrobiologia, 48: 127-148.

5. Kim L.H., Choi E., Stenstrom M.K., 2002. Sediment characteristics, phosphorus types and phosphorus release rates between river and lake sediments. Chemosphere, 50: 53-61

6. LAU S.S.S., CHU L.M., 1999. Contaminant release from sediments in a coastal wetland. Water Res., 33, 4: 909-918.

7. MCKAY G., 1996. Use of adsorbents for the removal of pollutants from wastewaters. CRC Press, Inc. 
8. Mosiej J., 1999. Przyrodniczo-techniczne uwarunkowania gospodarowania wodą w dolinie rzeki Ner. (Environmental and technical conditions of water management in the Ner River valley). Wydaw. SGGW, Rozpr. monogr., 222.

9. Multan H., 1993. Efekty i ograniczenia nawodnień wodami ściekowymi. (Effects and barriers in waste waters irrigation). W: Współczesne problemy melioracji. (The present problems of reclamation). Red. Cz. Somorowski. Warszawa, SGGW: 223-233.

10. Multan H., 1996. Zastosowanie systemów nawadniających do redukcji zanieczyszczeń ze ścieków. (Use of irrigaton systems for reduction of pollutants from sewage). W: Ochrona i zrównoważony rozwój środowiska wiejskiego. Red. T. Brandyk, P. Hewelke. Warszawa, Wydaw. SGGW: 268289.

11. Multan H., SzatyŁowicz J., 1993. Sprawność systemu nawodnień wodami ściekowymi w dolinie rzeki Ner. (Efficiency of wastewater irrigation system in the Ner River valley). W: Współczesne problemy melioracji. (The present problems of reclamation). Red. Cz. Somorowski. Warszawa, Wydaw. SGGW: 244-256.

12. PASŁAWSKI Z., 1992. Hydrologia i zasoby wodne dorzecza Warty. (Hydrology and water resouces in the Warta catchment). W: Ochrona i racjonalne wykorzystanie zasobów wodnych na terenach rolniczych w regionie Wielkopolski. Koreferaty i wnioski. Poznań, Urz. Woj.: 5-28.

13. Psenner R., PUCSKo R., 1988. Phosphorus fractionation: advantages and limit of the method for study of sediment P origins and interactions. Arch. Hydrobiol. Beih. Ergebn. Limnol., 30: 43-59.

14. Raporty o stanie środowiska w Wielkopolsce w latach 1997-2003, woj. łódzkim w latach 1994-2005, w woj. konińskim w latach 1995-1997 i woj. poznańskim w latach 1995-1996. (Reports on environmental status in the Wielkopolska Region 1997-2003 years; in the Łódź Region 1994-2005; in the Konin Region 1995-1997 and Poznań Region 1995-1996. Environmental Monitoring Library, Poznań, Łódź, Konin. WIOŚ.

15. SHEFFER M., 1998. Ecology of Shallow Lakes. St Edmundsbury Press Ltd. London.

16. Somorowski C., Multan H., Mosiej J., SzatyŁowicz J., 1991. Wpływ nawodnień ściekami na plonowanie i elementy bilansu wodnego gleby użytków zielonych w dolinie rzeki Ner. (Influence of irrigation on biomass yields and elements of water balance in grassland soils in the Ner River valley). Zesz. Nauk. AR Krak., 249: 81-101.

17. Stumm W., Morgan J.J., 1996. Aquatic chemistry. John Wiley \& Sons, New York.

18. URBANIAK M., 1997. Rekultywacja odbiornika ścieków miejskich. (Restoration of municipal sewage receiver). Ekoinżynieria, 11/12: 8-12.

19. URbaniaK M., PrZYBińSKi J., 1997. O etapowym rozruchu oczyszczalni ścieków i problemach $\mathrm{z}$ ustaleniem efektu ekologicznego. (On partial start-up of a wastewater treatment plant and assessment of ecological effect). Ekoinżynieria, 5: 16-20.

\section{STRESZCZENIE}

\section{Ksztaltowanie jakości wody w zdegradowanych odbiornikach ścieków na przykładzie zawartości fosforu w rzece Ner}

Słowa kluczowe: odbiornik ścieków, osady denne, rekultywacja, stężenie równowagi fosforu, uwalnianie fosforu

Rzeka Ner, mimo niewielkiego przepływu wody, wprowadza corocznie do Warty relatywnie duży ładunek zanieczyszczeń. Średni roczny przepływ Neru w analizowanym okresie wynosił ok. $10 \%$ przepływu Warty poniżej jego ujścia 
(ppk Koło), a udział ładunków fosforu wynosił 37\%. Stwierdzono brak odpowiedniej reakcji na zmniejszanie się ładunku fosforu odprowadzanego przez Łódź na jego zawartość w wodach Neru. Do 2000 r. ładunek fosforu w ściekach odprowadzanych do rzeki był większy od jego ładunku w profilu zamykającym Chełmno, co może świadczyć o procesach samooczyszczania. Jednak od 2001 r., po dalszym zmniejszeniu ładunku zanieczyszczeń w ściekach, ich ładunek w profilu zamykającym Chełmno jest większy od ładunku zawartego w ściekach. W warunkach małego stężenia fosforu w ściekach (poniżej $4 \mathrm{~g} \cdot \mathrm{m}^{-3}$ ) odprowadzanych z oczyszczalni, przy ujściu rzeki Ner nie obserwuje się odpowiedniego polepszenia jakości wody w profilu Chełmno. Mimo dalszego zmniejszenia zawartości fosforu w ściekach w latach 2002-2004, stężenie w ppk Chełmno nie spada poniżej $0,5 \mathrm{~g} \cdot \mathrm{m}^{-3}$, a w $2004 \mathrm{r}$. nawet zwiększa się do $1,1 \mathrm{~g} \cdot \mathrm{m}^{-3}$. Na podstawie wyników badań własnych dokonano oceny wpływu osadów dennych na zawartość fosforu w wodach rzeki Ner. Określono nie tylko zawartość fosforu w osadzie, ale również stężenie w stanie równowagi fosforanowej. Oznacza to, że każde stężenie fosforanów w rzece poniżej tej wartości będzie powodować ich uwalnianie $\mathrm{z}$ osadu. Z badań wynika, że w przekroju Puczniew stężenie w stanie równowagi jest większe od stężenia fosforu w wodzie i wynosi $9,5 \mathrm{mg} \mathrm{P}-\mathrm{PO}_{4} \cdot \mathrm{dm}^{-3}$, co oznacza, że gdy stężenie w wodzie będzie miało mniejszą wartość, fosfor będzie uwalniał się z osadu. Stężenie w stanie równowagi w przekroju Lutomiersk wynosi $1,2 \mathrm{mg} \mathrm{PO}_{4} \cdot \mathrm{dm}^{-3}$.

Reviewers:

Prof. Józef Koc

Prof. Andrzej Sapek 